\title{
ッングース人男子全身骨骼の一例に就て (二)
}

$\begin{array}{llll}\text { 石 裟 } & \text { 命 } & \text { 達 } \\ \text { 關 } & & \text { 政 } & \text { 則 }\end{array}$

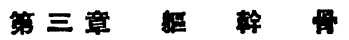

第一節 椎 肾

\section{一、藍骨前椎骨}

\section{特記事項}

椎骨數は頸椎 7、胸椎 12 、腰椎 5、合計 24 個あり。頸椎、椎體は一一般に大きく、低 く、上下面の形は略々腎臟形をなす。椎孔の大さは中等度、其形は第 3 上り第 7 迄は

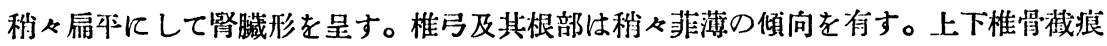
は大さ。深さ共に中等度。上下關節面突起は其高さ尋常。關節面は一般に稍々輕く凹 陷し、其傾斜は前上方上り後下方に走る度强し。前後絬節は發育寻常、頸動脉絬節は

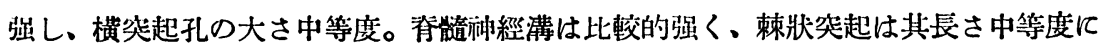
して Bifurkation は第 3 椎骨飞著岄なるも他は顯著ならす。。

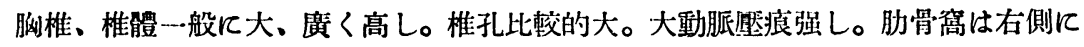
ては第 1 、第 11 、第 12 胸椎上肋骨窝は獨立し、危側にては第 1 ・第 10 ・第 11 及第 12 胸 椎上肋骨窩は獨立す。椎号及椎弓根は比較的强く、上椎骨擮痕は淺く、下椎骨截痕は 深し。上下關節突起は一般に高く、上關節面は平坦なるも下關節面は輕く凹陷す。模

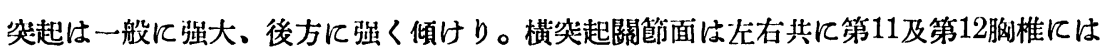
之を缺如す。梀狀突起は强大、第 5 胸椎上り第10胸椎迄は下方への傾科强し。

腰椎、5 個の椎骨上り成る。椎體大、廣く高し。上下面の形は圆味を帶へる腎臟形 をなす。椎孔は大、椎引は厚く、上下椎骨截痕は稍く大きく深し、上下關節兴起は高 く、上關節面は凹面をなして內向し、下關節面は凸面をなして外向す。横突起は第 3 腰椎が最も产く、第 1 腰椎の右側を除く外は總て發有强く左右に略く水坐に答出す。 
副突起、乳頭突起は發有稍々强く、䊂狀塋起は大にして比較的厚く殆ぞ水平位に近く 後方晌向ふ。

线域。大さ稍々大、側塊部の發有又强し。载域上關節窝の凹整は比較的弱く中央に

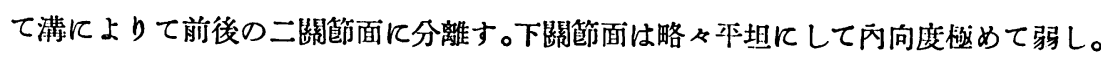

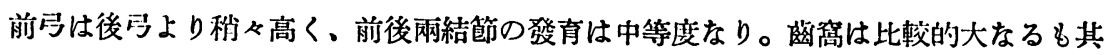
面圆形にして平坦に近し。椎骨動脈溝は著明、椎孔稍々廣し。

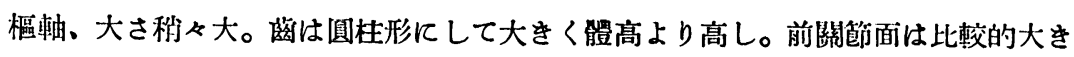
く上下に長き棈圆形をなし面は稍々左右に凸隆し上下に略く平坦なり。上距節面は其

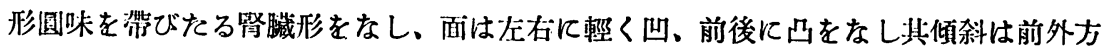
飞强し。

計测事項。

椎鰽垂道示數。

頸椎體て於ては第 4 第 5 镇椎體を除く外は總て現代畿內」日本人(畿內人)に比して大 なり。

胸椎體に於ては畿內人に比し、第 1 ・第 2 ・第 3 ・第11胸椎は小なるも他は凡て秒 ネ大なり。

腰椎軆に於ては义畿內人に比し第 5 腰椎を除く外は凡て大なり。郎ち畿內人に比し ては本例椎䐺は後高比较的大なり。腰柱前後垂直徑の示数は 107.5 Kして大きく koilorachisch (nach vorn konkav) 飞屬す。

椎触矢狀垂直示数。

䣆椎體に於ては第 3、第5は畿內人に比して秒々大なるも他は小なり。

腳椎體、腰椎體に於ては凡て畿內人上り可成小なり。即ち本例は椎體高に比して矢 爿徑が可成大なるを示せり。

椎體模垂道示數。

腳椎體に於ては第 2 、第3 胸椎の本示數岋畿內人上り大なるも他は凡て小なり。 腰椎䱏に於ては第 5 腰椎の示數を除く外は又總て畿內人上り小をり。郎ち本例は前高 に比して椎體中横徑大なるを示す。

载域矢狀横徑示數 (61.7)は畿內人に比し大なり。

载域椎孔矢狀横徑示數 (113.8)は畿內人上り大なり。 


$$
\text { 石濹・關ーツングース男子骨骼 }
$$

以上を要するに本萀骨前椎骨は 24 储より成り、其椎體の高さは略心中等度なるも矢 狀徑、横徑に大なり。

腰柱の前凹は可成强く koilorachisch なり。

二、菣 骨

特訅事項。

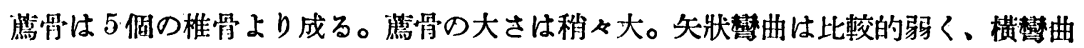

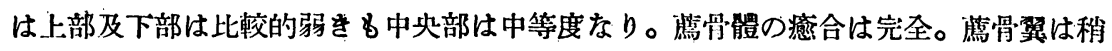
↔廣く、基底は homobasal に近く、岬角は稍々小なるも前方への凹出は稍々强し。 笉骨下方の尖銃は比較的鈍厚なるも其前凸度は比較的强し。耳樣面は比較的辰大にし て、其形成に甚るは第25椎、第26椎及第27椎の 3 椎骨なり。蔳骨管は稍々大、上方は 第25椎に始り、下方は第28椎にて開破す。椎骨破裂は第28椎より始まる。上關笁突起 は konvergenz 中等度、其面は刺く凹陷す。中菣骨櫛は第25至第27椎の 3 個の束束狀 突起より成り、各突起間の連續性强固なり。外藏骨櫛發育强く、蔦骨角は大にして右

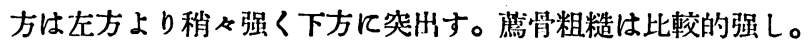

計测事項。

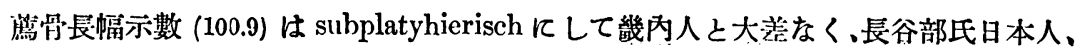
小金井氏日本人及北海道アイヌ人より稍く小なり。

弧長直幅示數 (91.1) は畿內人より大。弦高示數 (20.5) は畿內人と大差なく、第骨穹 俻高位造示數 (62.5) は少しく小。

弧弦示數 (90.3) は畿內人、アジア人、長谷部氏の日本人ょり大。郎ち賞萀骨は禁曲 比較的弱し。

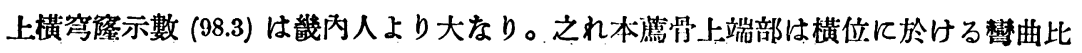
較的弱きに基因す。

上幅示數 (82.3)、中幅示數 (59.1) 及び全幅示數 (48.7) は何れも畿內人より小なり。 郎ち菣骨下方の小なるに因る。

䳡骨岬角 $\left(63^{\circ}\right)$ は畿內人及一般アジア人より小なり。

體矢狀橫徑示數 (60.3) 及び耳樣面長幅示數 (r. $\left.\begin{array}{l}\text { r. } 39.1 \\ \text { l. } 40.0\end{array}\right)$ は畿內人より著しく小なり。耳 样面長狹なるを示す。

弧長耳樣面示數 $\left(\begin{array}{ll}\text { r. } & 55.7 \\ 1 . & 52.4\end{array}\right)$ は畿內人より大。郎ち耳樣面の長大なるを示す。荿骨管示 
數 (48.6) は畿內人に近し。

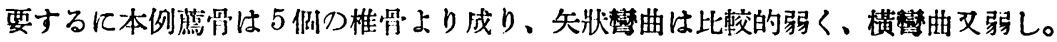
䉆骨上端部及中央部の幅大なるも下端部小。耳樣面は狭長なり。

尾䦚骨、缺如せるを以て略す。

三。答 柱

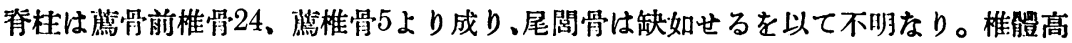

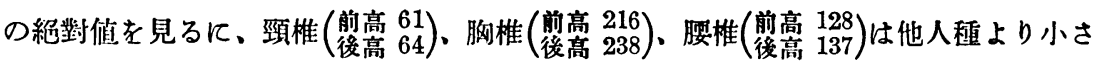
く且つ其各前高は後高より可成小なり。郎ち鹤骨前椎骨の部分に於ける筲柱は前凹せ

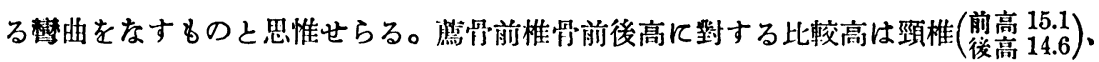

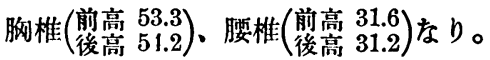

$$
\text { 第二節 胸骨 }
$$

特記事項

本例胸骨は胸骨柄と胸骨體とを保伃し、劍狀突起は缺如す。而して胸骨柄と骨能と は分離せり。

胸骨の大さは比較的大。胸骨角は中等度。胸骨柄は稍《大。比較的店右に廣く。厚

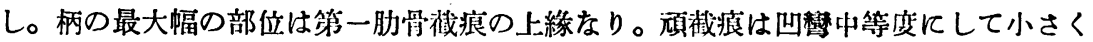
凹み、鎖骨截痕は大なり。

胸骨能は比較的大。比較的长く、廣く、稍々厚し。左右兩綵は上部第 3 肋骨截痕迄

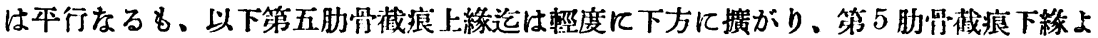
り下方は反之次第に狭小となる。而して縉の下端は右側が方側より稍々下方に突出す。 肋骨截痕は其大さ總て中等度にして左右六對あり。其中第 1 肋骨截痕及第 2 肋骨截痕

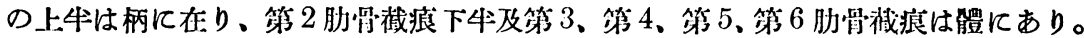

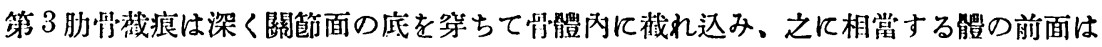
左右に一文字型に前方に稍々隆起し小解を作る。劍狀突起は之を缺く。

計测事項、比較すべき材料なきを以て省略す。

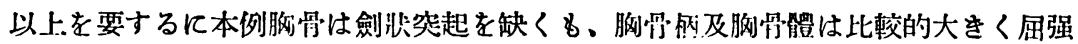
にして各ネ完全に分離し、六對の肋骨截痕を有す。

$$
\text { 第三節 助 骨 }
$$

特記事項 
肋骨數は12䍌。一般に細長にして面禁曲は比較的弱く、肋骨體の厚さは中等度なり。 胁骨小頭は中等大、小頭櫛は右側第 1 ・第 11 ・第 12 肋骨飞、左側第 1 ・第 10 ・第 $11 ・$ 第12肋骨に缺如せり。胁学頸の大さ中等度。项櫛及び肋骨結節の發達比洨的强く、肋

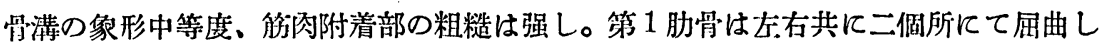
鎖骨“下動脉溝及び前斜角筋結節は顯著なり。第 2 肋骨粗徙又發達佳良なり。

計测事項

等曲示數以現代日本人に比し、第 1 肋骨は稍小、第 2 肋骨は稍大、第 3 ・第 4 ・第 5 ・ 第 6 ・第 7 ・第 8 肋骨は可成大、第 9 ・第 $10 ・$ 第 $11 ・$ 第 12 肋骨は稍大なり。

中央橫斷示數は現代日本人に比し、第 1 ・第 2 肋骨は著しく大、第 $3 \cdot \bullet$ 第 8 ・第12 肋骨は稍小、第 4 ・第 5 ・第 6 肋骨は可成小、第 7 ・第10肋骨は右側稍小なるも左側 は却て大なり、第 9 ・第11肋骨にて大差なし。

\section{第四章下肢骨}

$$
\text { 第一節 骨 盤 }
$$

㸱記事項

骨盤の大さ比較的大、高さ又高し。骨盤幅愿く、外深稍々深し。筋肉鞂帶附着部の 發育中等度。小骨盤容嫧は中等度、高さ比較的高く、萠骨下端は前凸度稍々强く、坐 骨の垂直位を保つ度稍々弱くして出口の狹窄の感は比較的强し。骨盤入口の大さは比

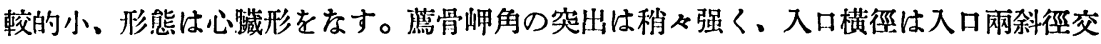
點の後方を通過す。分界線は第骨部中等度分朋、腸耻隆起以後の外方への䇾曲は稍々 强く、其缶曲の最强部は菣腸關節部より稍々前方にあり。腸耻隆起部の分界線は銳く、 之より前部は輕く內方へ凹勢を向くる弧狀をなす。

閉鎖孔は上下に長を略々卵圓形ををすも寗ろ其形は前內方に向ふ心側飞稍々膨出し、 此方を項點とし、後外方郎ち脾臼に近を側を底邃とする低き鈍角三角形をなす。

脾曰は比較的大きく、深く、前向の度稍々弱く、月㥞面は比較的廣し。耻骨角は著 しく小、耻骨弓の弧狀中等度、耻骨聯合は比較的高し。腸骨は其腸骨翼比較的大きく、

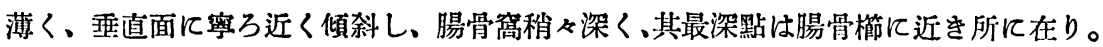

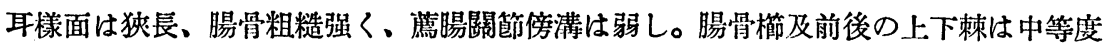
なり。坐骨は大さ中等度。坐骨棘比較的强く、大坐骨截痕は深し。坐骨結節の發育は 强し。耻骨は大さ中等度、耻骨結節も比較的强く、閉鎖溝は强大なり。 
㨽测事项

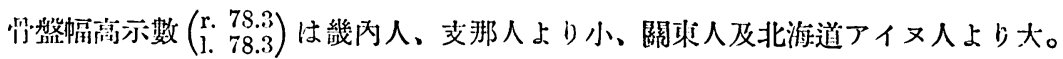

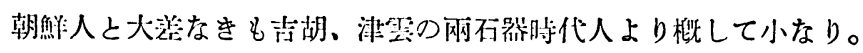

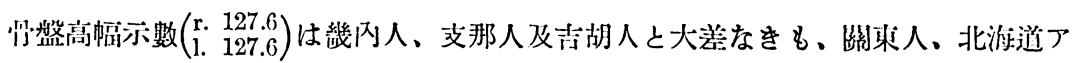
イヌ人より小、沬唇人よりは秒く大なり。

闭盤幅深示数 (63.2) は畿內人、アイヌ人及文那人と大美なく、關來人及日本不器時 代人より大なり。

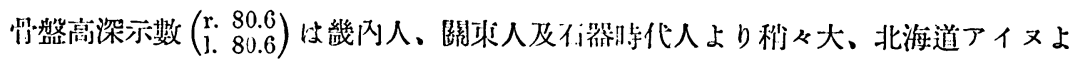
り小さく、文那人に近似す。即ち本例䗆盤は高、幅、深何れも比較的大なるを示せり。

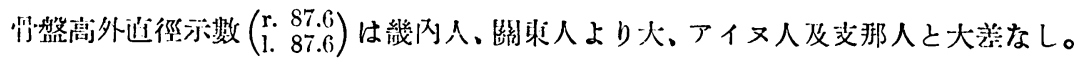

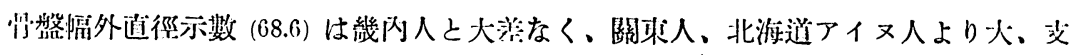
那人より小なり。

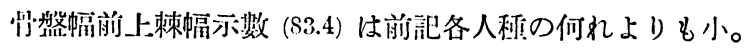

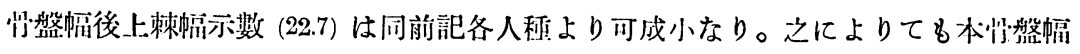
の大なるを知る可し。

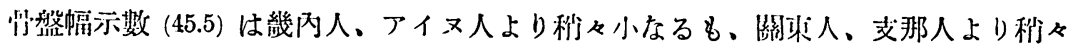
大なり。即ち简盤入口横徑の小なるを六せり。

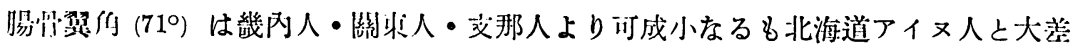

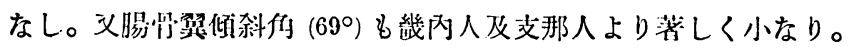

少然入口示数 (79.4) は各人称の们れよりも可成小なり。郎ち platypellischに国し。 沺盤黄通徑の小なるを示す。

背盤狄示數 (124.7) は支那人を除く外の各人利より小なり。即ち㫦盤怕口矢状徑の比 較的小なるを示せり。

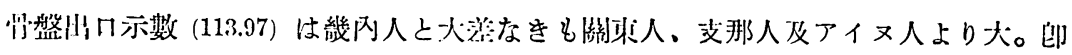
ち州口橫德は比較的小なり。

下耻闹的 $\left(40^{\circ}\right)$ は前記各人訸の们れよりも藷しく小なり。

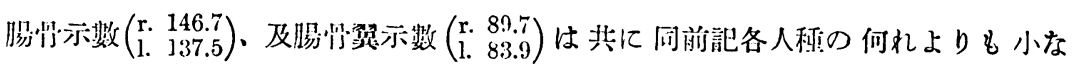

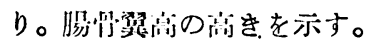

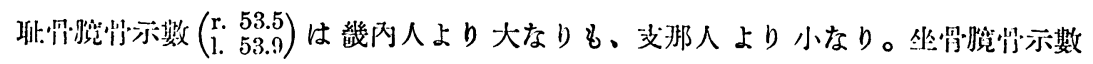




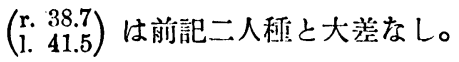

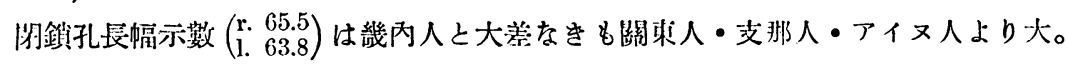
師ち閉鎖孔は長贋なり。

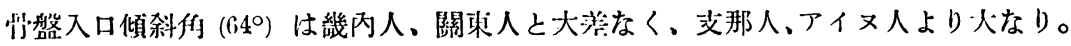

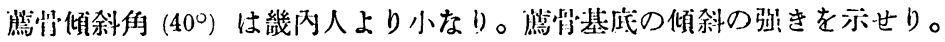

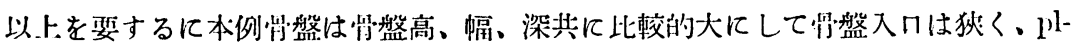

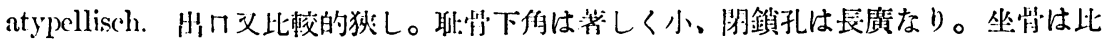

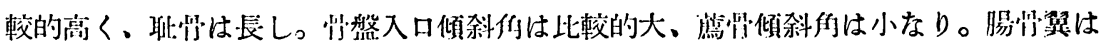

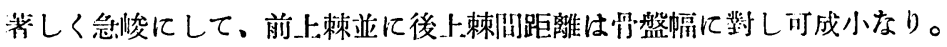

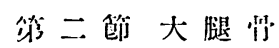

狩訑事项

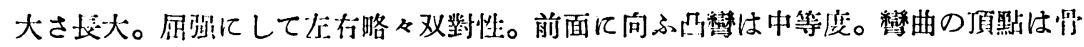

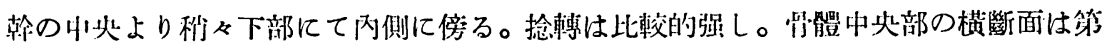

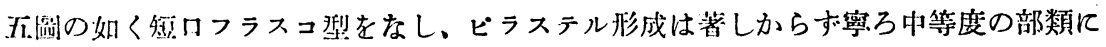

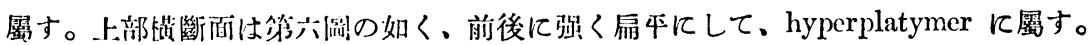
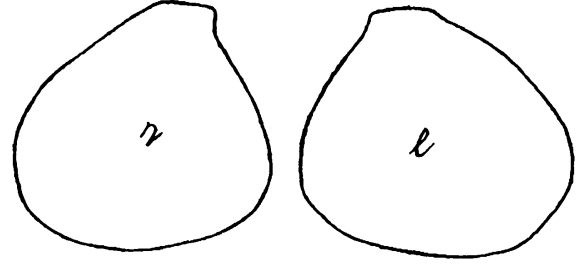

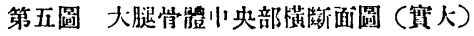

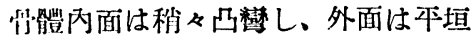
なり。骨體下方の摭りは喇叭狀。淢坦 面は平垣なるも稍々淺く凹陷す。搼荟 上.管は淺し、營養孔は右側は中央より 約 1 糧上方几て粗粘線に接し內方て在 り短小なる溝を經て上方に入る。左側

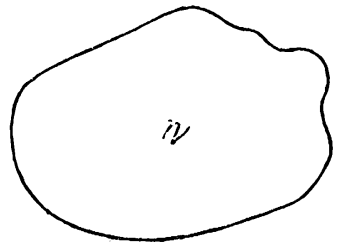

803

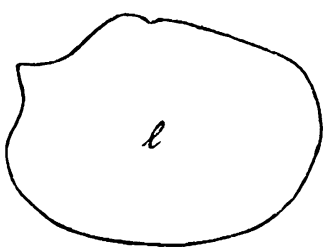

803

第六圖 大腿骨能上部橫㩰面圆（實人） は二侗ありて一は中央より約 1 糎下方にて粗徙線の內唇」に在 り、淺く短溝老件ひ上右に入 る、其孔口は中等大。他は小轉 子下端上り約 4.5 糎下方にて粗 料線上にありて孔口杫めて小さ

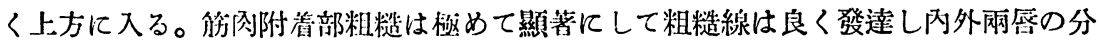
離朋かなり。內感は上方にて科線に移行し、下方は㮏嫺部に移行の途にて消失す。恥 


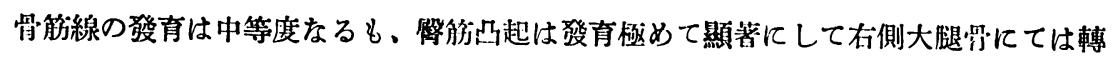
子下櫛となり上方に上るに從ひ大なる第 3 轉子となる。其長さ 40 籷、幅 15 粔、高さ約 9 粔の大さを有す。左側大煺骨に於ては义轉子下櫛をなして上り、長さ40籷。幅 12 籷。 高さ 8 籷の第 3 轉子をなす。共に小金井氏の規隻によれば「」なる第 3 轉子に屬す。 大轉子、小轉子、轉子間管は頗る强大、小轉子は內緗を超えて前面上り可見なり。

科線上結節は甚だ强大にして右側大艇骨にては長さ 20 籷、幅 15 粍、高さ 6 粍、左側 骨にては長さ19籷、幅14籷、高さ5籷の椅圆形の周園より朋かに分離せる結節をなす。 轉子間科線、科線下結節は反之頗る弱し。內側並外側骨上結笁は中等度。大腿骨滕㨡

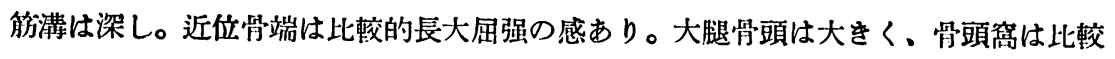
的大、前後に長き棤桍圆形をなし中等度の深さを有す。位置は下稍々後方儿偏く。大 腿骨頸は長大、前後徑比較的大、頸軸て對し骨頸面は稍々上向きの感あり。轉子窩は 深く大。遠位骨端は著しく肥厚し、近位骨端に對して大なり。大腿骨粗䊓線內唇と內 上髁との移行部郎ち大內轉股朌の附着部に長さ約 15 䊁。幅 5 粍乃至 3 籷の突起あり て、上記部位を基底として上內後方に細長く凸出す。之れ恐くは該解の琏が化骨せるも

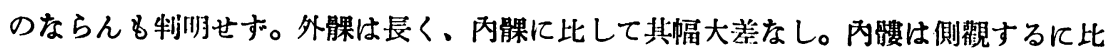
較的艮く長横棈圆形をなす。内外兩髁共に側面に向ひ膨隆す。滕荅面は外方著しく高

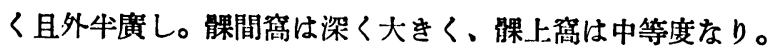
計测事項。

中央横斷示數 $\left(\begin{array}{l}\text { r. 93.3 } \\ 1.90 .3\end{array}\right)$ は畿內人・關東人・樺太・北海道兩アイ邓人・北支那人及朝 鮮人の们れよりる小なり。郎ち矢狀徑よりも横徑大にして在右上りも前後に扁平にし て、ピラステル形成は著しからさるを示せり。

强硬示数 $\left(\begin{array}{l}\text { r. 13.2 } \\ \text { 1. 13.4 }\end{array}\right)$ は畿內、關東兩人より大、苹太アイヌ人上り小なるも、マルチン 表に於ける世界諸人種の掌示數に比して高く、當大腿骨の屈强度强きを示せり。

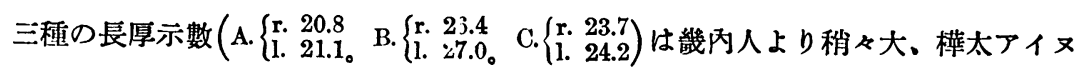
人より稍く小なるも一般に Europïer, Mongoloiden 上り大にして强硬なるを表はせ b。

上部横斷示数 $\left(\begin{array}{l}\text { r. } \\ \text { l. } 70.3\end{array}\right.$ 70.3 $)$ は前記各人種の何れよりも小さく、谜しく前後に扁平にして hyperplatymer $儿$ 屬す。

頸横斷示數 $\left(\begin{array}{l}\text { r. } 80.6 \\ \text { l. } 80.6\end{array}\right)$ は反之同諸人種の何れよりも大なり。 


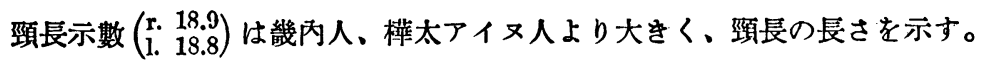
頭横斷示數( $\left(\begin{array}{l}\text { r. 1 102.0 } \\ \text { 100.0 }\end{array}\right)$ は怔徑、縱徑殆ど相等しく圆形を䉆すてとを示し、畿內人より 稍ぬ大。㯜太アイメ人に近し。

骨幹長頸周徑示數( $\left(\begin{array}{ll}\text { r. } 31.3 \\ \text { l. 30.1 }\end{array}\right)$ は畿內人、アイヌ人上り大、项の周圍が比較的太きを示 せり。

上鲤骨翰長示數 $\left(\begin{array}{l}\text { r. } 22.1 \\ 1.22 .1\end{array}\right)$ は畿內人、苹太アイメ人と大美なし。

下部横斷示數 $\left(\begin{array}{l}\text { r. } 48.3 \\ \text { l. } 49.1\end{array}\right)$ は前訅兩人より小なり。

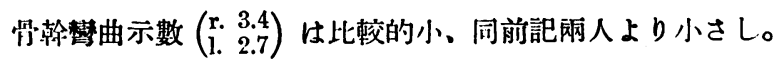

揄轉角 $\left(\begin{array}{l}\text { r. } 16.5 \\ \text { l. } 16.5\end{array}\right)$ は現他人としては大なる部類に屬す。畿內人・權太アイヌ人及關東 人上り頗る大なるも、吉胡人、津雲人、石器時代人よりは小なり。

頸體角 $\left(\begin{array}{l}\text { r. } 78^{\circ} \\ 1.78^{\circ}\end{array}\right)$ は著しく小にして當大搉骨の頸部は届曲谌だ强をを示せり。前記各 现代諸人種より著しく小なり。

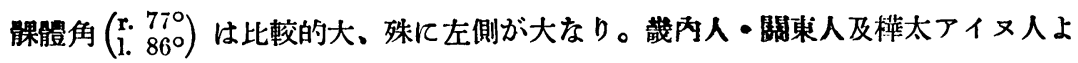
り少しく大なり。

以上を要するに本例大晴骨は左右共に骨幹長大、屈强にして慗曲は中等度なるも捻 轉强く、兩骨端比較的强大、筋肉附着部8又强し。骨翰中央部は、ビラステルの形成 著しからさるも、上部は hyperplatymer に屬し扁本度强し。骨頭は大にして圆く、頸 は太く長く、頸體角は著しく小。鲤體角は比較的大、殊て左側にて大なり。

$$
\text { 第三節 膝蓋骨 }
$$

\section{特記事項}

大さ比較的大。左右略々同大。形態は栗子狀なり。

Hohe Patella 及 Mittelbreite Patella 亿屬す。內側關節面は外側關節面より狒し。 右側滕荟骨は內、外兩側關節面輕く凹陊す。左側骨は外側關節面は輕き凹陷をなする。 內側關節面は夹坦なり。隆線は中等度なり。

計测事項

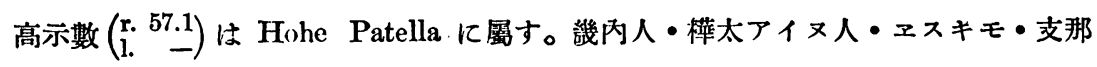
人の何れよりも高し。

幅示數 $\left(\begin{array}{l}\text { r. 54.1 } \\ \text { l. 54.1 }\end{array}\right)$ は mittelbreite Patella 亿屬す。畿內人・蓝太アイヌ人及支那人上 り小さく、ヌスキモに近似す。 
高幅示數( $\left(\begin{array}{rr}\text { r. } \\ \text { l. 100.0 }\end{array}\right)$ は畿內人及樺太アイヌ人より大なり。 厚幅示數 $\left(\begin{array}{l}\text { r. 52.2 } \\ \text { l. 47.8 }\end{array}\right)$ は又前記兩人上り大なり。

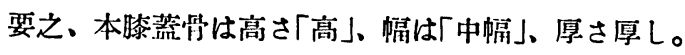

第四筧 脛 骨

特記事項

大さ長大。形態左右不同。右側脛骨は完全なるも、左側骨は骨翰中央より外側にて 下方約 55 籷の所より、內側面にて約 110 籷の部の間郎ち長さ約 55 籷の部分は科に外上 方より內下方に向て走る不完全なる骨の癒合線を表はす。其假骨形成に乏しく骨變化 の陳答なる所より見れば之は你命中庈側下煺の骨折を受け、其後上䚶の如き形狀に不 完全なる䯚瘾着をなして治瘾せるものならん。䳕めに中央部より外側下方約 55 籷の所 にて外方に高さ10籷の骨篮起を生じ、又內側面にて中央部より下方約 110 粍の所は輕 き隆起をなして全骨長に於て稍々短縮を來せり。兩側脛骨共に其甾强度は稍々弱し。

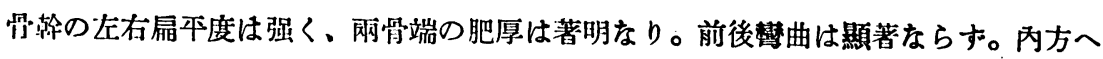

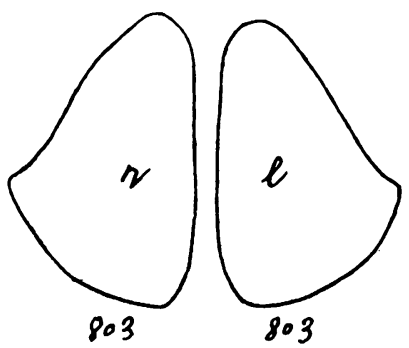

第七圖 脛骨中央部㯕断面圖(察大)

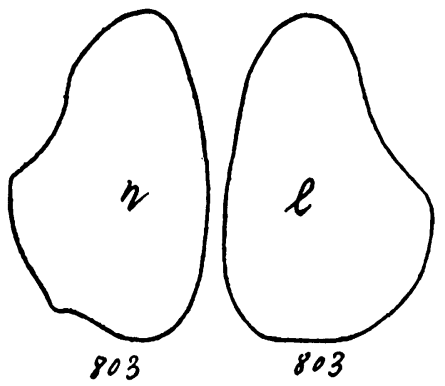

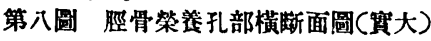

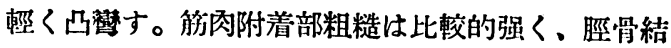
節は良く發育せり。骨體中央部の横斷面は第七圖の 如く、左右扁平の强きを示せり。前饰は比較的尖銳 にして、骨䦌櫛又銳く、內側面は平坦、外側面は凸 隆を呈せり。橰膕線は著明にして左右共に上三分の 一部にて消失す。榮食孔は右側脛骨にては後面上方。 骨間櫛と睩膕線との中間にて稍々長き溝を伴ひて下 方に入る。左側脛骨にては後面上方中央にて稍々 長大なる溝を件ひ下方に入る。榮食孔部の骨幹横 断面は第八圖の如し。近側骨端は比較的大、外髁 面整曲度は「トムソン」氏圖の第 2 型に相當す。

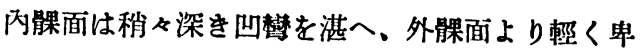
下す。後俯及傾科は稍々弱し。髅間隆起は可成强 し。遠側骨端は比较的大、內踝は中等大にして、 內踝溝は淺し。「非骨被痕の深度は中等度なり。 計测事項 


$$
\text { 石澤・關ーツングース男子骨鮥 }
$$

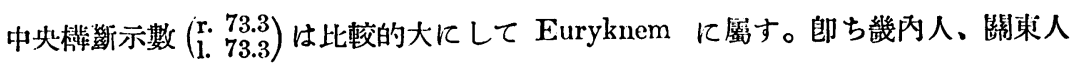
より僅かに小なるも、櫵太アイヌ人・北海道アイヌ人及北支那人上り大なり。

榮食孔部橫斷示數 $\left(\begin{array}{l}\text { r. 64.9 } \\ \text { l. } 67.6\end{array}\right)$ は比較的小にして Mesoknem に屬す。北海道アイヌ人を 除く外各人種より小なり。

長厚示數 $\left(\begin{array}{l}\text { r. } 20.9 \\ \text { l. }\end{array}\right)$ は畿內人・樺太アイヌ人・Mongoloiden 上り小さく、從つて本例 脛骨は屈强度弱し。

長上幅示數 $\left(\begin{array}{l}\text { r. } 22.0 \\ \text { l. }\end{array}\right)$ は畿內人、樺太アイヌ人より小なるる、北海道アイヌ人より大 なり。

長下滆示數 $\left(\begin{array}{ll}\text { r. } & 14.3 \\ \text { l. } & -\end{array}\right)$ は畿內人より小さく、樺太アイヌ人より大なり。郎ち脛育長の 比較的大なるを示す。

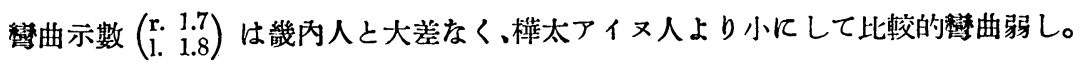
捻轉角 $\left(\begin{array}{l}\text { r. }+9{ }^{\circ} 0 \\ \text { l. }\end{array}\right)$ は畿內人、關東人及檴太アイヌ人に比して遥かに小さく、捻轉度 弱し。

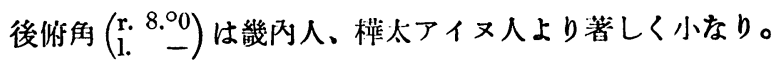

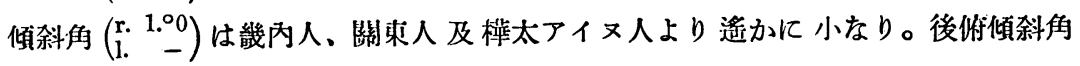
$\left(\begin{array}{l}\text { r. } 7 . \circ 0 \\ \text { l. }\end{array}\right.$ - $)$ は畿內人より大なるも榡太アイヌ人に近似す。

之を要するに、本例脛骨は細辰にして屈强度弱く、南翰の中央部は Euryknem に、

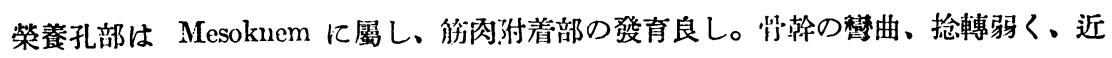
位骨端の後稱、傾斜又弱し。

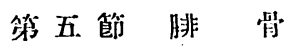

\section{牛护記事項}

形態細長にして扇平ならす。略々畺直に近し。然し腓骨に於ても左側骨は、中央部 より下方外側櫛にて約 60 䊈の點上り、队側面にて約 110 籷の點の間郎ち長さ約 50 粍の 部分は骨折後の不完全骨癒着を痕し、該部分は稍々前後に廣く肥厚し骨隆起を生じ。

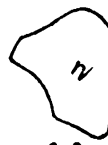

803

第九圖 腓骨中央部烧

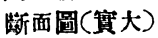
全骨長に稍々短縮を來せり。中央橫斷面は第 9 圖の如し。中央 部最大徑は前節と後面間にあり。䯈間櫛・前・內・外各櫛は凡 て稍々銳し。队側面は凹陷溝老示する。外側面及後面は輕き凹 禁を是せる平坦面をなす。腓骨小頭は稍々大、不正楕圓形をな

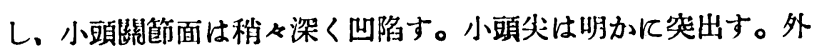
医和 6 年 5 月 
踝は强く下方に突隆して大きく、閵節面は略々三角形をなす。

計测事項

中央部橫斷示數 $\left(\begin{array}{l}\text { r. } 85.7 \\ \text { l. } 80.0\end{array}\right)$ は萻しく大なり。即ち畿內人、關束人、樺太、北海道兩ア イヌ人より遙かに大なり。

長厚示數 $\left(\begin{array}{l}\text { r. 12.3 } \\ \text { l. 12.4 }\end{array}\right)$ は畿內人より大、潇太アイヌ人と大坃なし。

渠之本例 非骨は細脣にして骨翰整曲弱く、网骴端比較的大なり。

第六篩 足趾虰

…距骨

特訅事項

大さ比較的大。形態は比較的長高なり。上面大さ秒々大、後方に輕く塽小となる。

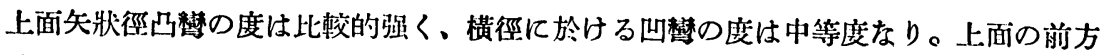
頸部に向ふ延長は內側に强く、外側に弱し。洕車は慗く前外方上り後內方に走る。滑

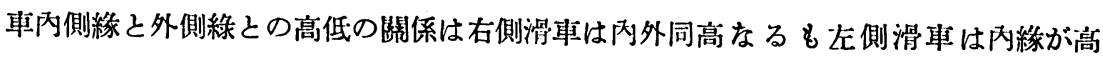
し。內踝面は比較的大きく、前方は强く頸部に延く長し、後方は長く伸延して後距骨脛 骨鞂帶附着部に到達す。队踝面は前部は比較的緩く內下方に傾科するも中央部及後部 は垂直に近く傾く。外側笑起は比較的弱く、下端尖銳ならす。外踝镃節面の凹度は

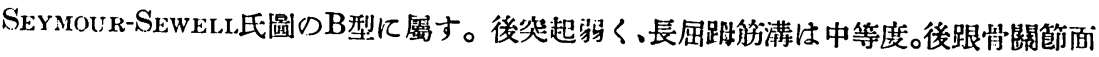

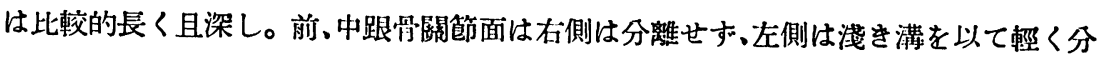
離さる。足立氏の前外下部の小關節面は線條椂に微かに認めらる」のみ。距骨頸は短

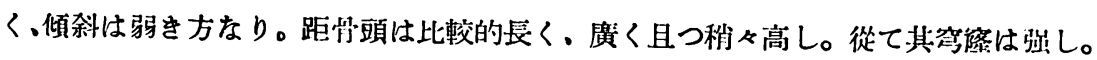
計测事項

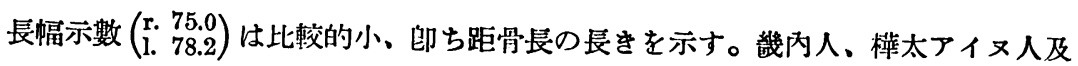
北支那人より小さし。

長高示數 $\left(\begin{array}{l}\text { r. } 58.9 \\ \text { l. } 60.0\end{array}\right)$ は一般に大美なく、距骨は比較的高し。

滑車辰幅示數 ( $\left.\begin{array}{l}\text { r. 85.3 } \\ \text { l. 85.3 }\end{array}\right)$ は小さく、滑車は長狹なり。郎ち各人種の何れよりも小なり。 滑車長高示數 $\left(\begin{array}{l}\text { r. 29.4 } \\ \text { l. 29.4 }\end{array}\right)$ は可成大、滑車は滈し、即ち畿內人及樺太アイヌ人より大な り。

滑車長示數 (r. 60.7 $\left.\begin{array}{l}\text { r. } 61.8\end{array}\right)$ はさく、滑車艮は距骨長に比して短し。郎ち畿內人、樺太ア イヌ人及支那人より小なり。 
滑車幅示數 $\left(\begin{array}{l}\text { r. } 83.3 \\ \text { l. } 83.3\end{array}\right)$ は比較的大、前後幅の差小なるを示す。即ち各人種より大なり。 距骨滑車幅示數( $\left(\begin{array}{l}\text { r. 69.1 } \\ \text { l. } 67.4\end{array}\right)$ は一般に比較的大。滑車は距骨幅に對して比較的廣し。郎ち 滑車は狹長、塽高なり。

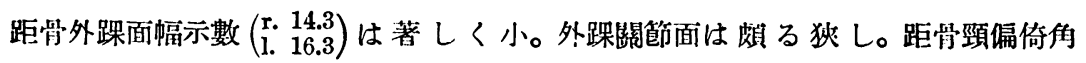

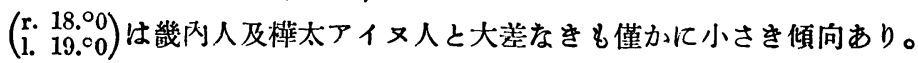

頸距骨示數 $\left(\begin{array}{l}\text { r. } 37.5 \\ \text { l. } 36.4\end{array}\right)$ は頗る小。頭頸長は距骨長に對し短し。即ち畿內人及樺太アイ ヌ人に比し著しく小なり。

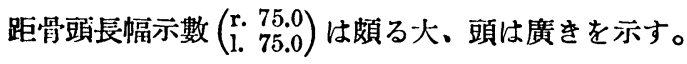

頭長高示數 $\left(\begin{array}{l}\text { r. } 40.6 \\ \text { l. } 43.8\end{array}\right)$ は比較的大、頭の高きを示す。

距骨頭捻轉角 $\left(\begin{array}{l}\text { r. } 30^{\circ} \\ \text { l. } 40^{\circ}\end{array}\right)$ は畿內人、樺太アイヌ人より小なり。

後跟骨關節面長幅示數 (r. $\left.\begin{array}{l}\text { r. } 63.8 \\ \text { l. }\end{array}\right)$ は畿內人及樺太アイヌ人上り著しく小。同長深示數 $\left(\begin{array}{ll}\text { r. } & 23.5 \\ 1 & 24.2\end{array}\right)$ は畿內人、樺太アイヌ人より大なり。即ち後跟骨關能面は狭く深し。同關節 面偏倚角 $\left(\begin{array}{l}\text { r. } 48^{\circ} \\ \text { l. } 41^{\circ}\end{array}\right)$ は比較的小。前記丽人より稍々小なり。

以上を要するに本例距䇰は比較的長高、滑車は狭長且狹高。其前後横徑の差は小な り。外踝面は頗る狹く、頭は廣く長く其穹隆比較的强 L。頸は短く、其傾科弱し。後 跟骨關節面は比較的深狭なり。

二、跟 号

特訅事項

大さ比較的大。長く廣く且つ高し。體の內側の凹陷は比較的深く、上面郎ち跟骨隆

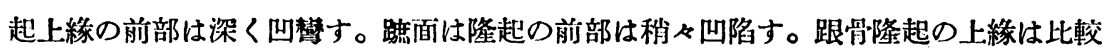
的銳く突壮し、隆起踣側部は大さ中等度。跟骨隆起內側突起は强く、外側突起は弱し。 隆起と跟骨體との境界は分朋なり。後關節面は比較的大。長く廣く且つ高し。前、中 狀節面は連續せるも輕く稍々前部にてくびる。载距笑起は廣く、稍々高し。跗骨萁は 比較的大。骰子骨關節面は比較的大。廣く高し。下方の境界は尖銳。滑車笑起は强く。 長屈跳觔溝及長腓骨筋溝は比較的深し。

\section{計测事項}

中幅最大長示數 $\left(\begin{array}{l}\text { r. 55.0 } \\ \text { l. } 57.1\end{array}\right)$ は畿內人と大差なく、樺太アイヌ人よりは大なり。

最小幅全辰示數 ( $\left.\begin{array}{ll}\text { r. } 34.2 \\ \text { l. } & 35.1\end{array}\right)$ は畿內人及支那人より小、樺太アイメ人に近し。即ち前記

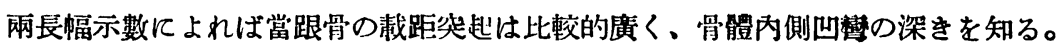


長高示數 $\left(\begin{array}{l}\text { r. } 55.3 \\ \text { l. } 56.8\end{array}\right)$ は畿內人及樺太アイヌ人より稍々小。小高全長示數 $\left(\begin{array}{ll}\text { r. } 52.6 \\ \text { l. } 54.1\end{array}\right)$ は前 詎两人及支那人より大なり。

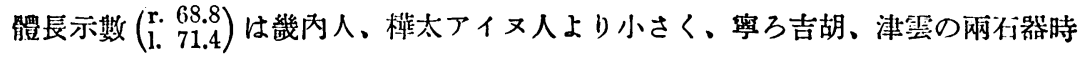
代人に近し。

截距突起示數 $\left(\begin{array}{ll}\text { r. } & 36.4 \\ \text { l. } & 34.1\end{array}\right)$ は大。饮ち载距突起は廣きを示せり。畿內、蓝太アイヌ网人 より大なり。

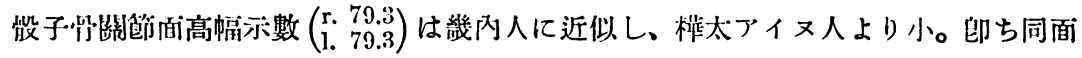
は比較的低し。

跟产隆起幅高示数 $\left(\begin{array}{ll}\text { r. } & 62.8 \\ \text { l. } & 62.8\end{array}\right)$ は比較的小さく、隆起は狄淿なるを示5。间高骎示數 (r. 63.8$)$ は比較的天にして隆赺の高きを裴はす。

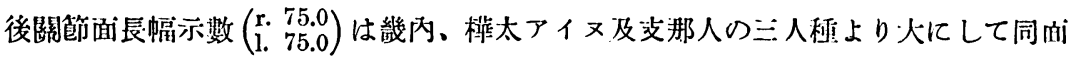

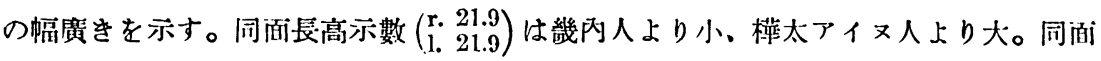
偏倚牦 $\left(\begin{array}{l}\text { r. } 47^{\circ} \\ \text { l. } 39^{\circ}\end{array}\right)$ は前記网人上り大なり。

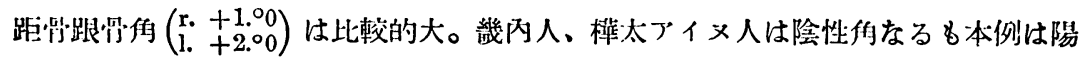
性角にして、吉胡人、津臨人の石器時代人上りは遥汃に小り。

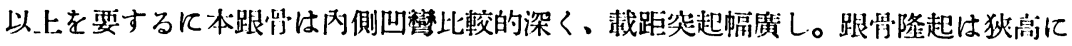

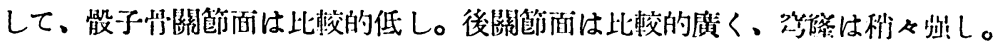

三。舟师赑

\section{特記事项}

大さ比較的大、黄く河成高し。内牛、外牛共に厚く且つ內牛は外卅に比して更に厚

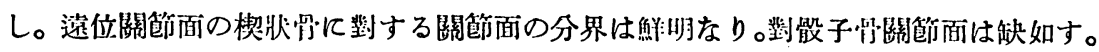
舟狀学兟起は大なり。

部测事項

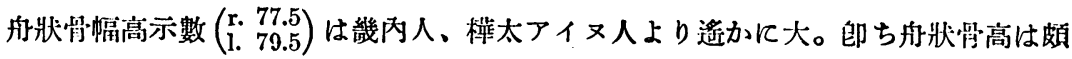
る高し。

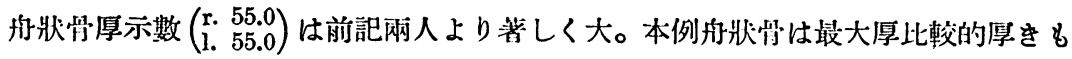
最小厚又頗る厚く、网厚の厚さの恙甚だ大なるを示せり。

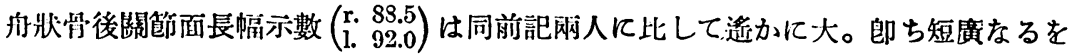
表す。同面長深示數 $\left(\begin{array}{l}\text { r. 19.2 } \\ \text { l. 20.0 }\end{array}\right)$ は同爾人より小さく、同面の淺きを表せり。 


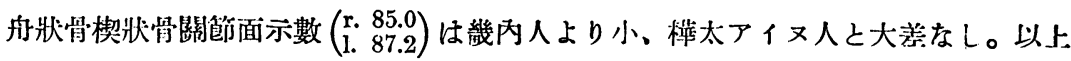
を要するに本舟狀骨は頗る高く且つ厚し。後寎篩面は比較的淺く短廣なり。

四、楔狀骨

特訅事項

第一楔狀骨、大さ比較的大。比較的高く、近位端中等度なる8遠位端高く、其兩省 の高さの比大なり。裳位端面は略々平坦にして腓骨側面に於ける第二蹠骨との關節面 は比較的强し。

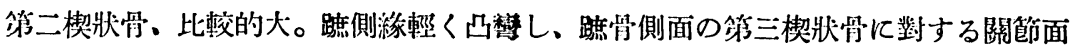

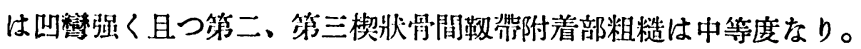

第三楔狀劣、大さ比較的大。遠側面は秒々哚く凹陷し、近側面は平坦なり。第四蹠

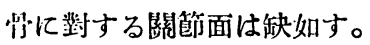

塥测事項

第一楔狀峭長高示数 $\left(\begin{array}{ll}\text { r. } & 126.9 \\ \text { l. } 126.9\end{array}\right)$ は畿內人、樺太アイメ人上り大。不器時代人に近し。 郎ち本楔狀骨は比較的高し。

第一楔狀骨高示數 $\left(\begin{array}{ll}\text { r. } & 137.5 \\ \text { I. } 137.5\end{array}\right)$ は前記网人より大なり。

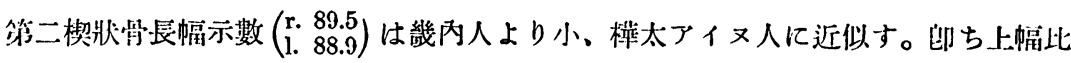
較的狄し。

第三楔狀骨長幅示數 $\left(\begin{array}{l}\text { r. } 69.6 \\ \text { l. } 69.6\end{array}\right)$ は前記丽人より叮成大なり。

第三楔狀骨幅示數 ( $\left.\begin{array}{l}\text { r. 92.3 } \\ \text { l. 92.3 }\end{array}\right)$ は畿內人上り稍々大なるも、樺太アイヌ人より可成小な り。

以上を要すると第一楔狀骨は比較的高く、遠側高大なり。第二楔狀骨は上幅比較的 狭し。第三楔狀骨は上幅廣し。

五、骰子步

阽訩事项

大さ比較的大。近位端面の鞍狀度は比較的著しく、遠位端面凹稫は中等度なるも。 同踣骨關節面相互の境界は可成分明なり。外緗は內緣に比して著しく短く、腓骨朌溝 及骰子骨凸起は强く、後蹠面への錐形乫起は可成顯著なり。

i测事項

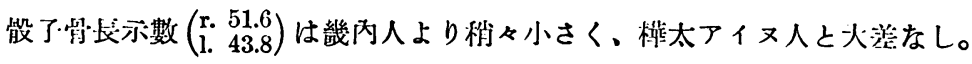


公、蹠骨及趾第

特記事項

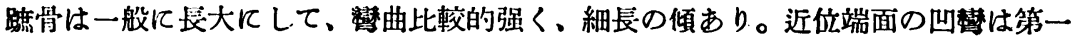
第二、第三蹠骨は比較的強く、第三及第五踇骨は弱し。小頭の穹荥は强く、面は狭長 なり。第一蹠骨凸起は比較的强く、脛骨側への轉向は强し。第 5 蹠骨凸起は稍々厚く 長し。

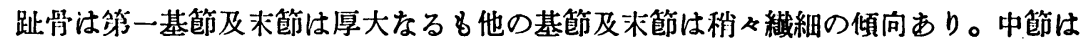
之を缺く。其他一般に尋常にして特訅すへき事項を認められず。

計测事項

蹠骨長の辰短順位は II, III, IV, V, I なり。

蹠骨比較長、は畿內人上り小、苹太アイヌ人に近し。

第二蹠骨は比較的大にして、不器時代人に近し。

蹠骨捻轉角

本例蹠骨榦の捻轉㐿は總て庁側が右側上り大なり。大略畿內人及權太アイヌ人より 大なり。

趾骨基節比較長

畿內人に比しI 及IIは略々近きも。III，IV，V，は秒々小なり。櫵太アイヌ人に比 しIは近似するも他は凡て大なり。

基節長は一般に小さく、第一基節長が第二基節長より大。基節長の長短順位は I, II, III, IV, V なり。

之を要するに本例の蹠劣は捻韩角は一般に强大にして、趾骨基節は一般に短し。

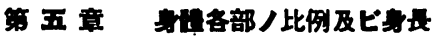

身能各部の比例

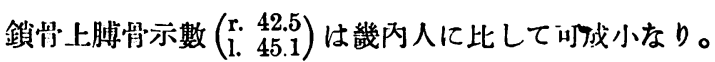
上膊骨橈骨示數 $\left(\begin{array}{ll}\text { r. } 67.8 \\ \text { l. } 69.6\end{array}\right)$ は畿內人より小。

挵骨長尺骨長示數 $\left(\begin{array}{l}\text { r. 90.6 } \\ \text { l. 91.7 }\end{array}\right)$ は畿內人及北海道アイヌ人より小さし。

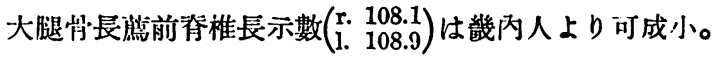

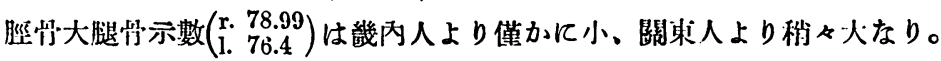
脛骨腓骨示數( $\left(\begin{array}{l}\text { r. } \\ \text { l. 100.0 } 101.1\end{array}\right)$ は畿內人及樺太アイヌ人より大なり。 


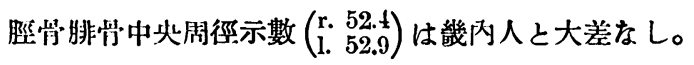

跟骨距骨银示數 ( $\left.\begin{array}{l}\text { r. 73.7 } \\ \text { l. 74.3 }\end{array}\right)$ は畿內人より稍々大。

跟骨距骨幅示數 (r. 95.5 $\left.\begin{array}{l}\text { r. } 97.7\end{array}\right)$ は畿內人上り稍々小。

上下肢骨示數 $\left(\begin{array}{l}\text { r. } 71.0 \\ \text { l. } 71.1\end{array}\right)$ は畿肉人より稍々大。

大腿骨上膊骨示數 $\left(\begin{array}{l}\text { r. } 75.8 \\ \text { l. } 73.9\end{array}\right)$ は畿內人上り叮成大。

脛骨橈骨示數 (r. 68.9 (1. 70.2) は畿內人より大なり。

渠之、本例は上膊に對して前膊比較的短く、橈骨に對する尺骨長は比較的長し。大 腿骨は篤前脊椎長に比して短し。上下腿の比侧は大差なきも僅かて脛骨が大腿骨に對 し短く、上下肢の比例は上肢が下肢に比し大。大腿骨は上膊骨に對して短く、脛骨は 橈骨に對して短し。

次に、ピアソン氏係數式に依り大眼骨、上膊骨、脛骨及橈骨の四肢長骨長上り生時 身長を推算するに、上膊骨長を基礎とせる身長數 (167.88) 最も大、脛骨長を基礎とせ る身長數(163.72)最も小去り。四骨各長を以て按排せる數 (165.63) は最も平均値 (165.53) に近し。即ち本例ッングース人 人骨の生時身長は 165.53 なりと推定す。該身長は Jochselson-Bronsky 氏による Tsunguse (Gischiga) の身長 ○ 156.5， +146.5 に比す るに頗る大にして本例人骨はツングース人中にても長大なる身長の持主と推定さる。 台其他の東部亞細亞人の Aino, Koreaner, Koriaken, Giriaks, Chinese 等の身長に比 较するも本例は大なり。(末完) 